\title{
"The Role of a Yoruba Traditional Leaf in a Fermented Food Technology (Nauclea Latifolia, Sarcocéphalus Latifolius): Shedding Light on African Accuracy of Implicit Knowledge and Technologies"
}

\author{
Segla Dafon Aimé \\ Epistémologie, Histoire des Sciences et des Technologies \\ Culture, Science, Technologie et Etudes sur L'Innovation \\ Université d'Abomey-Calavi / Université de Parakou, \\ République du Bénin (Afrique de l'Ouest) \\ Akpona Simon \\ Epistémologie, Histoire des Sciences et des Technologies \\ Culture, Science, Technologie et Etudes sur L'Innovation \\ Université d'Abomey-Calavi / Université de Parakou, \\ République du Bénin (Afrique de l'Ouest)
}

\begin{abstract}
Starting from the foundational archaeology of concepts in language and cognition of an archaic fermented food technology in a society of oral, we try to demonstrate the accuracy of implicit traditional knowledge. Semantics and concepts are here cultural traces of hidden knowledge. The phytochemical analysis of the leaf which serves as food package shows it as well. And thus, we argue that Africa must "museumize" its ancient technological practices, yet at the same time, start with the said practices, in view of establishing a foundation for the much needed innovation in African societies.
\end{abstract}

Key words: Africanizing science and technology; concepts: language and cognition; implicit knowledge; knowledge production; innovation: studies-technological.

\section{INTRODUCTION: SITUATING THE PROBLEM}

In this paper, we try to elucidate, using a foundational archaeology of concepts taken from fermented food technology among some Yoruba linguistic groups in Benin Republic - the Yoruba-Idààsha and the Yoruba-Shabè in central Benin Republic -, the accuracy of implicit African knowledge (Sègla 2015a, 2015b, 2016). After a brief survey ofYoruba history and its early agricultural system, we illustrate our claim by the study of a leaf that encapsulates fermented food and that shows antitoxic, antioxidant, organoleptic, and antimicrobial qualities leading to extended food conservation of up to 15-30 days. Known scientifically as Nauclea latifolia or Sarcocéphalus latifolius, the concerned here leaf is very rare today. It is called /Ewé egbessin, leaf of egbessin/ in Yoruba language. However, it is still used by women that know its nutritional values in history of the society. In present days, the uses of leaf to package meals are replaced by plastics which are very toxic. The multiple usage of a same plastic to package meals and its non bio-degradability is source of many dangerous hygienic and toxicity problems leading to permanent contamination of meals in nowadays African society (Fagbohoun et al. 2013). In this context, the usages of leaves to encapsulate meals can represent valuable alternatives to toxic non-biodegradable plastics. Some leaves which are popular in market places in Benin republic have been studied by scholars such as Fagbohoun et 
al. (2013) and other scholar in Benin Republic. Fagbohoun et al. (2013) studied the leaf and the essence of Teck plant, the Tectonagrandis. Zannou, Gbaguidi and Ahoussi-Dahouenon (2016) studied Tectonagrandis, but also Thaliageniculata, Lasiomorphasenegalensis and Musa acuminate. All these leaves are used as food packing ing in Benin Republic but the fact is that, in case of Tectonagrandis (Fagbohoun et al. 2013), or Thaliageniculata, Lasiomorphasenegalensis and Musa acuminate (Zannou, Gbaguidi, and Ahoussi-Dahouenon 2016), the extended food conservation does not exceed 3 or 4 days whereas that of the leaf concerned here in this study, /Egbessinleaf, Nauclealatifolia/ is up to 15-30 days "1". Unfortunately, this knowledge is lost in history and only very few women continue the ancestral practice. The concerned meal is very liked in West Africa. People call it /eko or egbinrin eko/ in Yoruba lands in Nigeria, Benin and Togo. It is generally called /akassa/ in Benin Republic but also /gui/,/lio/or /akumè/ among the Fon, Mina or the Guen in Benin, Togo and Ghana. The meal is so popular and in these conditions, a semantic reconstitution that shows cultural traces to an ancestral food technology that used a rarefying today leaf with high microbiological qualities leading to extended food conservation of up to 15-30 days is cautiously engaging.

We then suggest the possibility of the production of scientific knowledge in situ. Indeed, in modern days, the production of science and technology in Africa neglects large parts of the empirical African world and the ancestral productions are constantly challenged by the production of foreign nations (Sègla 2017). Thus, fostering science and technology under these conditions means addressing a lack of empirical knowledge by working on science and technology in situ. Such a project that is socially and economically less expensive than relying only on the mimicry of Euro-American science and technology implies the possibility of several other projects that engage millions and millions of African workers for national growth. The case study of a fermented food technology which uses biological epistemology and semantic reconstruction from Idààsha and Shabè dialects of Yoruba may suggest a reinterpretation of the importance of implicit knowledge in the African and other non-Western cultures (Sègla 2003). In this study, we first briefly talk about the Yoruba history and culture, the ancestral agricultural system and the methodology. After that comes the study of the leaf of /Egbessin/ for packaging /egbinrin eko/.

\section{BACKGROUND OF THE YORUBA PEOPLE}

The Yoruba number about 50 million people. They live in West Africa, principally in Nigeria, Benin and Togo (Igué 1970) (Fig.1). Millions of others are descendants of enslaved Yorubas in Cuba, Brazil (Bahia) and the United States. The origins of the Yoruba are lost in history. Their ancient history, some time between $3000 \mathrm{BC}$ and $5^{\text {th }}$ century AD (Horton 1979 ; Obayemi 1979), is well known by the study of the pre-dynastic Yoruba linguistic groups, the preOduduwa peoples now mainly in Benin Republic, Togo or in the eastern parts of Yoruba land in Nigeria. Their recent history began with the foundingof Ifè between $5^{\text {th }}-8^{\text {th }}$ centuries $A D$, and later with the foundation of Oyo.

Their culture and heritage is widespread, and reflects well-developedknowledge in all domains including art, whichoriginated in the Ifè Classical period (1000 to 400 AD), and which had a tradition of excellence comparable to the works of art of Classical Greece and Rome (Willet 1967)

\section{MATERIAL AND METHODS: PROCEDURE}

Arguments are brought from interviews with traditional peoples whom knowledge and practices survived Western colonial contact and remained immune from Western post colonial hegemony. Data was gathered from the Yoruba Idààsha and Shabè, as well as the Bariba, who are close neighbors of the Yoruba. The data addressed earlier pre-colonial constructions rather 
than echoes of European contacts (Sègla et Boco 2006; Sègla 2008, 2015a; Apter 1987). Informants were interviewedin the village of Kèrè in Idààsha country, the village of Atata in Shabè country and the village of Bourarou/Badé in the Parakou area ofnorthern Benin. The pre-dynastic or the pre-Oduduwa Yoruba whose memory and cultural traces go back to the Classical Yoruba Period give evidence of archaic and conservative cognitive constructions. They share a lot of claims of aboriginal status with clusters of ancient cults; or they give evidence of archaic ritual language forms, echoing earlier spoken dialects, like Ifè tutu or Isha tutu / which mean 'the first Ifè or Isha,or the Ifè and Isha of early times', earlier spoken dialects of which the nowadays archaic Idààsha dialect of Yoruba, in particular, is reminiscent (Sègla et Boco 2006; Sègla 2008, 2015a). It is interesting to note that many of these archaic language forms and items still resurface in the voices of possessed ancient cult worshipers and devotees who are most often peasants in Idàs̀sha and Shabè countries. Yoruba women and their Bariba neighbors still retain their semantic authenticity andstill use traditional leaves from ancient times to wrap their meals. The most prominent leaves are

1- /éwéègbessin//theègbessin leaf/ (in the Idààsha dialect of Yoruba; /éwéigbessin/ (in the Shabè dialect of Yoruba); also called /garérou/ (in Bariba language);

2- /éwékpakpa//thekpakpa leaf/(in Idààsha and in Shabè) also called /gbaba/ (in Bariba); and,

3- /éwénhouin/ (in the Shabè dialect of Yoruba; /koumi/ in the Bariba language). However, in this study, special attention is paid to the/éwé igbessin/or/éwéegbessin/, Nauclea latifolia or Sarcocéphalus latifolius (Fig. 2). Particularly interesting is the name given to the meal which was encapsulated in ancient times by the said leaf. The meal is called /égbirineko/ which means /the meal that is encapsulated, spin-dried, protected/, an idea which is, as we will see further, cautiously linked to the chemistry and the nature of the leaf /éwé igbessin/. The meal is so spin-dried that it appears nearly immune from toxicity and infestation for about 15-30 days.

\section{THE ANCESTRAL AGRICULTURAL SYSTEM}

To put it briefly, except for the Yoruba-Ajasè in the town of Porto-Novo in southern Benin who are recent rich immigrant traders from Nigeria, the other Yoruba who migrated from what is now Nigeria, between 2000 BCE and 1000 CE (Horton 1979; Obayemi 1979), are poor peasants living in the savannah. Their soils being of poor quality, they developed and adapted an agricultural system that helped themsurvive and live. Their year begins in December, after the first moon, which means in the language system /Ekondun/, /first lunar interval/ the prefix /okan/or/ekon/ indicating 'one'. Two other monthly intervals follow, but these are viewed as being unproductive because they correspond to a period when a very dry wind blows and does not allow agricultural activities. These are called /Alemokini/, which means /first idle time/ and /Alemokéji/ which means /second idle time/. They correspond respectively to /January to the beginning of February/ and to /the end of February to the beginning of March/. Thus, the effective year begins in April-May when rain falls abundant for sowing. Seed-sowing thus ran from April or May and the productive season would end in September. This is a short agriculturally productive season during which, in order to avoid food shortages, the preOduduwa, pre-dynastic Yoruba in the Idààsha and Shabè countries had to work hard to feed their families and perform their ritual ceremonies. Obviously, due to these austere conditions, people also developed techniques of food conservation.

Food conservation techniques vary with different Yoruba pre-dynastic groups in Togo and Benin. But generally, originally, the people had atuber-basedcivilization until theXVI century, when people began to change to cereal-based food habits, with the introduction of maize, sorghum or millet, etc. into society. In ancient times, when yam (a tubercle) was pounded andpeople wanted to conserve it, this was done by being dried under the sun. After maize and 
sorghum were introduced in the XVI ${ }^{\text {th }}$ century, people tried to dry their meals after cook from thenew introduced cereals but the practice mostly failed. People then searched for other ways of conserving meals. The process led to techniques of wrapping meals with leaves. Every leaf can have its role. Some meals can be eaten without any sauce because when they are encapsulated, they capture the aromas of the leaf in which they are encapsulated, whereby the smell and the flavor act as a sauce. That is the case of the /cassava/ leaf, very well-known for giving a good aroma and taste to the encapsulated meal. That is also the case of the leaf of /carica papaya/ (the taxonomical botanical name of the pawpaw leaf), which was used in ancient times for the encapsulation and the conservation of various meats that the hunters brought home from the forest. In fact, it is because the leaf of /carica papaya/ made the meats softer. Of course, it has been proven that the /papaïne/ which is the chemical agent in /carica papaya/ has the ability to stop infection.

After the colonial period, traditional ancestral leaves were largely abandoned or neglected, having been replaced by commercial post-colonial leaves/trees that were exclusively aligned with the colonizer's international trade interests. And thus, these leaves have become very rare today. Of greater consequence is that with the recent phase of globalization, we see the introduction of plastics in the food industry, a practice that contributes to the disruption and disorder of the earth's ecosystem (Fig. 3). With the use of plastics which are non-biodegradable for the traditional food industry, the core problem is that the plastics, which are being used many times over for different meals are very easily contaminated, thereby provoking hygienic and toxic accidents because the meals contained in plastic packages are infected.

\section{CASE STUDY OF /EGBINRIN EKO/ WITH /E(I)GBESSIN/ LEAF PACKAGE}

/Egbinrineko/ is a meal made of fermented maize powder. That meal is given the name 'Akassa' in West African francophone countries. Once cooked, the meal is encapsulated with leaveswhich are rare today. /Egbessin/ is the name of the plant or leaf in this case study. Informants attest that it encapsulates the meal for at least 15 days without producing bacteria.

\section{Foundational Archaeology of Concepts}

Let us explore the linguistic and terminological semantics of /egbinrineko/ or the shortened name of it, /egbinrin/ (the meal made of fermented maize).

/Egbinrin/, in the Idààsha dialect of Yoruba, means /a meal encapsulated in a leaf/. In the language system, /egbinrin/is/what is hidden in leaf/, or /what is hermetically protected by the leaf/ "2". Semantic reconstruction can make it clearer:

- /gbin/ (in egbinrin) is to sow, to put in soil and cover, to plant. It means 'putting seeds into the earth to grow after rain fall' "3". Whereas, /rin/ means / todry by tight squeezing or extraction/. For example, when a king died, his body was mummified. It is said that his body was spin-dried, expressed in the language system as /throwing (extracting) the blood (liquid) from the body/, a practice that is still in usein today's Idààsha Kingdom. Another example is that, after you wash a piece of clothing and subsequently attempt to dry it, the language system uses the word/rin/, meaning /to wring or squeeze away water from it/ "4". Similarly, as for clothes or for the blood of the deceased King, the leaf in which food is encapsulated makes it remove away bacteria and microbes from the meal, and as such, we can say that the leaf spin-dries the meal in a way that ensures the meal is conserved for a long period of time.

\section{Ethnography Shows: The Depth of the Archeology of Concepts}

Gathered data from informants shows that the semantics accord well with the ethnography. In the village of Bourarou, suburb of Parakou in northern Benin, two women named Ms.Adama, 
31 years old and Ms. Bougnon, 75 years old, attest that "mobou" (the local Bariba name for/egbinrineko/), when encapsulated in the /garerou/ leaf (local name of the leaf /ègbessin/), last from 15 to 30 days before it perishes. Ms.Adama and Ms.Bougnon added that once the hot meal is encapsulated in the leaf, the meal is placedinside a traditional gourde (calabash) which offers the meal its organoleptic quality. In addition, Ms. Adama and Ms. Bougnon explained quite vividly that the gourde has a property that enables it to concentrate the heat from the meal, thereby boosting the spin-drying and purifying the meal, thus implying the elimination of bacteria and microbes (Fig. 4, and Fig. 5).

In the village of Kèrè in Yoruba-Idààsha country in central Benin Republic, as well as in the village of Badé in Bariba country, a suburb of the city of Parakou in northern Benin Republic, collected information was cross-checked and attested by women who are still sellers of /egbirineko/. In the village of Badé for instance, Ms. Na Bipibou recounted the relevant story “5":

"I have been a seller of 'ma bou' since my little age; $i$ have been taught the preparation of /ma bou/by my parents since birth; /ma bou/ is good meal but people don't know; /ma bou/ has proved to be effective since the ancestral period; I will continue to sell /ma bou/ even if the /garérou/leaf is rare today for and it is a pain for me to cut it"

When asked why people don't know why /ma bou/ is a good meal, Ms. Na Bipibou said "6": "They say /ma bou/ has a slightly bitter taste and flavour and is colored; they say they don't like colored meals; but they ignore that the color is from the liquid (effect of a colorant from the leaf of course) and it is the colorant that protects the meal from perishing; they prefer meal encapsulated in today's plastics; they don't know that the heat from the meal dangerously decomposes the plastic and also consequently the meal, which is infected very quickly; plastics are not good; it is our ancestral practice that is safe and not dangerous" (Fig. 6, and Fig. 7). When Ms. Na Bipibou was talking, Mr. Sambani Issifou, a man of nearly 35 years old was seating there and was listening. $\mathrm{He}$ is a herbalist and traditional healer. He could spontaneously add to Ms. Na Bipibou's speech "7":

"People hate what our forebears knew, but that was good; it is because the bitter taste of the leaf is beneficial that our forebears used it to encapsulate the meal; our forebears knew that when you have a stomach ache (stomach pains) and you take /ma bou/in a /garerou/leaf, your pain disappears immediately; the /garerouleaf is a medicine; that is why our forebears used it; they also used the root of the tree that produces the leaf to cure many diseases, among which are the cleansing of stomach, hernia, gynaecological problems, etc." (Fig. 8)

\section{DISCUSSION}

\section{Comparative Analysis of Phytochemical Contents}

According to ethnography and field work data, it appears that the traditional leaf /ewe egbessin/ (Nauclea latifolia or Sarcocéphalus latifolius) has a high organoleptic quality. Moreover, as testified by the women who make this food, it shows antitoxic, antioxidant, and antimicrobial qualities leading to extended food conservation of up to 15-30 days. It is clear that the antioxidant, antitoxic and antimicrobial activities are due to the presence of many polyphenol agents which are colorant molecules responsible of the yellow and red color of the meal as described by Ms. Na Bipibou (Fig 7). In fact, it is known in vegetal biology that the polyphenol agents, including Flavonoides, Tannins, Quinones, Terpenes, Steroids, Coumarines, Mucilages, and Saponosides, reduce free radicals that are reactive oxygen species. These substances inhibit the destabilizing action of the free radical within the meal /egbinrin eko/. Obviously, the use of Ewe egbessin leaf by traditional women is not by chance. The relevance of 
the practice can be proved by results of studies on similar leaves that are not rare as it is the case with /ewe egbessin/. We have mentioned some of these similar leaves above. The works of Fagbohoun et al. (2013) and Zanou et al. (2016) on Tectonagrandis, Thaliageniculata, Lasiomorphasenegalensis and Musa acuminate show it quite vividly. We borrow from Zanou et al. (2016) who reported from Bruneton (1993) to make clearer the relevance of traditional practice. According to biologic properties of the chemical compounds being in plant species following Bruneton (1993), all species of plants whose extracts contain the Tannins, the Flavonoïdes, the derivatives quinoniques, the Saponosides, the Terpèneses and the Steroids, etc. are antiseptics and therefore capable of acting as packing likely to play a role in the conservation of food. All these species contain at least an antibacterial, an antiviral and/or a fungicide (Zannou et al. 2016; Bruneton 1993). According to Bruneton (1993) and Zannou et al. (2016), the mentioned species contain the food complements that can act as antioxidant, anti-inflammatory, antiallergique, antitumoral, vasculoprotectorand/or vein trope (Bruneton 1993; Zanou et al. 2016).

Apart from the antioxidants present in the leaf of /Egbessin/ (Nauclea latifolia or Sarcocéphalus latifolius), several colorants that attest to the color given to the meals are monitored and standardized by the local people. They are useful in other domains, like in Orisha/Vodoun Deity Worshiper's beauty art. They also have a big and positive impact on local arts and crafts.

\section{How Traditional Illiterate Peoples Know Theoretical Things at the First Stage}

We are dealing here with the 'tacit knowledge' or implicit knowledge of traditional peoples as introduced by Michael Polanyi $(1958,1983)$. Tacit knowledge is of silent availability because the evidence of its existence can not be made explicit, but it represents the silent capacities of the human body, of the language and the rituals, which means that people may always know more than they are able to say (Polanyi 1958, 1983). Sibum (1998) has brought a similar and interesting study about the experiments of Joule. Joule was studying the nature of heat, and he used the implicit knowledge of the art of brewery as a guide. Brewery was, at the beginning of the Victorian period, a primarily practical craft that could be attained only by practical work, all the more because beer brewers were neither able to read nor write. And yet, even though they knew, for instance, nothing about the theoretical meaning of the fermentation process, "the beer brewers were able to determine the effect of yeast during the conversion of sugar into alcohol", or they were able to "determine the density of the substance after pressing by using their fingers" (Sibum 1998:760). In sum, Sibum says that "what has conventionally been regarded as Joule's "personal" or "tacit knowledge" is better conceptualised as embodied knowledge, rooted partially in a hitherto unknown tradition of early Victorian brewing culture" (Sibum 1998:744; 1995a, 1995b). Michael Polanyi explained quite vividly in his works, the intimate connection between explicit scientific knowledge as shown in the laboratory and implicit knowledge as expressed by women from oral traditional culture for "to see a problem is to see something that is hidden" (Polanyi 1983:23). The present case study on fermented food technology among the Yoruba, illustrates major points in the current debate on how to sort out knowledge and technologies in oral societies African contexts (Sègla 2015a, 2015b, 2016). Semantic reconstruction from semantic relics or clusters of archaic languages and interpretations seem here to represent important historical layers of cultural traces of knowledge in Yoruba history and culture (Sègla et Boco 2006; Sègla 2008, 2015a). Studies that seek to sort out a particular form of knowledge production show that traditional technical achievements seem not to simply be a description of static ideas that are best understood as historical markers but rather, they are like logical, psychological and dynamic transformations. 


\section{Hibridity or Non-Hibridity}

This case study of knowledge production from anindigenous food technology among the Yoruba, traces an African experience which is now gradually recognized in terms of supporting the validity of tacit or implicit Endogenous / (Indigenous) Knowledge Systems (IKS). The paper resonates strongly with this, and thus, providing a case study that makes real some of the broader contexts of the IK system that are not usually problematized in African Studies. The original study utilizes the example of food preservation amongst pre-Yoruba groups still living among the Yoruba in modern Benin republic to make the case for a more historically and linguistically-nuanced understanding of IK. While paying close attention to socio-linguistics, onto-epistemologies, geographies, pre-colonial and colonial histories, and the colonial archive of technologies and sciences in Africa, the main focus here is how the traces and paths of inherited knowledge can be outlined without an unacceptably simplistic distinction between the "Western" and the "African". It seeks to deal with how science tackles the unexpressed, the unformulated, the paranormal, the implicit, and the tacit within African societies today.

Most importantly, the paper refers to colonization as the 'great rupture' where indigenous knowledge was first lost or stolen. It may well be true that the kind of knowledge production that is studied here existed before coastal European contact with local peoples (Sègla 2015a, 2016). But without taking the risk of falling into the domain of received wisdom, the following question can be raised: What processes of validation are there? "Was there no hybridity?", "no contestation?", "no transaction?". Mudimbe $(1988,1994)$, in his drawing of one thing deriving from one another thing in different ways and from different perspectives, and Morgan Hodge's 'Triumph of Experts' (2007) in which he explores the development of science during the colonial and post colonial transition - are both useful outlooks to consider here. Can it merely be that the colonizers, under the framework of imperialism during the $18^{\text {th }}$ and $19^{\text {th }}$ centuries, came with the Western sciences which they deployed in the new colonies and were designed to serve the economic and other interests of imperialistic regimes? If true, Western sciences were in this case considered to be rational, while the practices of colonized peoples were, in the eyes of the colonial administration, irrational and therefore uninteresting scientifically. Thus, the role and place of so-called native knowledge - for example, biomedical indigenous knowledge was not clearly identified and differentiated by the colonizer. Studies from the ' 80 's in the $20^{\text {th }}$ century on imperial and colonial medicine confirm the difference (Arnold 1988; MacLeod and Lewis 1988). Even though there are several different approaches to these examinations, all of them unanimously describe Western medicine and bio medical studies as being a social and political power of great meaning in the lives of the colonized people. Conversely, the role and status of the so-called indigenous knowledge - for example, the local biological and medical knowledge of the natives against epidemics - is not adequately discussed in these studies. As such, it is understandable that the case study in this paper of a Yoruba food technology was ignored by the colonizer, having replaced traditional ancestral leaves with exclusively commercial post-colonial leaves/trees aligned with the international European trade interests. And thus, the consequence of this was that these leaves became rare.

However, it seems true, as introduced by Mudimbe $(1988,1994)$, that, no one thing replaces the other, but that there is only the constant and continual working out of something which results in new things, that draw one from the other in different ways and from different perspectives (Mudimbe 1988, 1994). This idea of Mudimbe's, can also be seen in Morgan's work in his 'Triumph of Experts' (Morgan 2007) in which he explores the emergence of scientific expertise during the colonial-post colonial transition. It suggests that there may be a possibility of thinking through 'travelling technologies' a little more to encapsulate some of the issues raised. 
In this paper at least, we see a certain hybridity in some way; that is to say, a travelling of knowledge and technology in situ. In fact this traveling is not between the European and the African but between African sorts of knowledge themselves. Indeed, the practice described here was originally that of the Yoruba. But in the paper we see how this knowledge and knowhow moved from Yorubaland to its northern neighbors, the Bariba, in what is now Benin Republic, the people who fundamentally are the only ones in Benin who still truly conserve and continue to practice the originally Yoruba food technology today. Yet, it is interesting to emphasize, as in other works, the problematization of the idea of the colonial period as the 'great rupture' where indigenous knowledge was first lost or stolen. This exercise, although difficult, would be useful to answer the questions concerning the antithetical study of the relationship between IK and the colonial encounter. Perhaps, here lays the bus ticket. Or, what sort of historically informed research do we need to uncover the movement of seemingly context-bound indigenous technologies?

\section{CONCLUSION}

Monitoring and developing methods of research that help understand the dynamism of traditional knowledge is engaging. In a collective project of intellectual, moral and spiritual revival for African self-realization, the African scholar must return to Classical periods to find out scientific and technical achievements, to take charge of the discrete, tacit and implicit knowledge. Finally, a study that began from a fermented archaic food technology and semantic reconstruction of pre-dynastic root-morphemes in a Yoruba Idààsha and Yoruba Shabè archaic dialects may suggest new indexical guidelines for the search for the memory of knowledge, techniques and practices. To put it in another way: how do people with expertise in different ontologies deal with techno-scientific models and evidentiary practices? This set of urgent and diverse questions that African societies pose can help to (re)think the localized character of scientific knowledge.

If the paper traces a case of an African (Yoruba) experience of gradually recognizing and supporting IK System, the question of the transformation from a tacit to a codified system still remains. Tacit versus codified knowledge, who then could codify the tacit knowledge, and what processes are next for concrete innovations, in view "restoring African society to scientific and technological agency? These questions might help spur further investigations in the domain of science and technology policy making in African governments. The main question which remains is: how do we create a civil society that is connected to scientific and technological developments, and that is capable of questioning and engaging with industrialization? This study should be deepened through microbiological analysis for more consolidated results. For instance, extracts from the leaf must be tested on fungi or bacteria to prove their degree of antifungal or antibacterial efficiency. Quantities of fractioned elements may be listed and presented in graphs. Graphs of lethal (toxicity) tests must show the lethal dose of poisonous substances in the leaf. In addition, graphs of identified antioxidants may be shown. It would also be interesting to investigate the physics of the traditional gourdes materials used by the women food makers to further clarify its exact role in the process of packaging.

* ACKNOWLEDGMENT NOTE: "1"

Oral conversations with /égbinrin/ women sellers in village of Kèrè Igbo-Idààsha (DassaZoumè), November 2013

\section{References}

Apter, Andrey. 1987. "The historiography of Yoruba myth and ritual." History in Africa 14:1-25.

Arnold, David (ed). 1988. Imperial Medicine and Indigenous Societies. Manchester: Manchester University Press. 
Aimé, S. D., \& Simon, A. (2018). "The Role of a Yoruba Traditional Leaf in a Fermented Food Technology (Nauclea Latifolia, Sarcocéphalus Latifolius): Shedding Light on African Accuracy of Implicit Knowledge and Technologies". Advances in Social Sciences Research Journal, 5(2) $200-212$.

Bruneton, Jean. 1993. Pharmacognosie : Phytochimie, Plantes médicinales. (2e édition). Technique et Documentation. Lavoisier, Paris.

Fagbohoun, Louis, Mathe Carole, Gbaguidi Fernand, Ayédoun Abel, Moudachirou Mansourou, and Vieillescazes Cathy. 2013. "Phytochimie, cytotoxicité et évaluation de l'activité de l'extrait méthanolique des feuilles de tectona grandis L.f. (Verbenaceae) utilisées dans l'artisanat agroalimentaire au Bénin ”. Demi-Journée Tersys. Université d'Avignon et des Pays du Vaucluse, France.

Horton, Robert. 1979. “Ancient Ife`: a reassessment”. Journal of the Historical Society of Nigeria 9(4):69-149.

Igué, John. 1970. La Civilisation agraire des Populations Yoruba au moyen Dahomey et au moyen Togo. Thèse de IIIe cycle. Paris.

MacLeod, Roy, and Lewis Milton. 1988 Disease, Medicine and Empire. London: Routledge.

Morgan, Hodge. 2007. Triumph of the Expert: Agrarian Doctrines of Development and the Legacies of British Colonialism. Ohio University Press.

Mudimbe, Valentin-Yves. 1988. The Invention of Africa. Gnosis, Philosophy, and the Order of Knowledge. Bloomington: Indiana University Press.

-. 1994. The Idea of Africa. Bloomington: Indiana University Press.

Obayemi, Ade. 1979. “Ancient Ife`: Another cultural-historical interpretation”. Journal of the Historical Society of Nigeria 9(4):151-185.

Polanyi, Michael. 1958. Personal Knowledge. Chicago: University of Chicago Press.

-. 1983. The tacit dimension. Gloucester, Mass: Peter Smith.

Sègla, Dafon, Aimé. 2017. " Techniques ancestrales écologiquement intensives: méthodes non chimiques de conservation des grains de maïs dans une communauté villageoise du Sud-Ouest du Bénin (aja-dogbo) ". Journal Revue d'Ethnoécologie, Musée des Sciences de l'Homme, CNRS Paris. Forthcoming.

-. 2016. "Viewing Formal Mathematics from Yoruba Conception of the Sky". Oxford Conferences Series X Astronomy and Interpretation. Journal of Astronomy and Culture JAC Vol.1 $\mathrm{N}^{\circ} 1$, pp 9-21, University of California Press.

—. 2015a. "Yorùbá Ethno astronomy: Orisha/Vodun or how people's conception of the sky constructed science". In Clive, Ruggles (ed). International Handbook of cultural astronomy. Springer Science New-York.

- 2015b. "Chasing the Shadow of the Sun: The Batammaliba's Binary System of Time". In Brian, Patrick, Abbott (ed.). Inspiration of Astronomical Phenomena VIII: City of Stars, ASP Conference Series Vol. 501 Astronomical Society of the Pacific (ASP) / The University of Chicago Press Journals, San Francisco, New-York.

—. 2008. "The Cosmological vision of the Yorùbá-Idààisha of Benin Republic (WestAfrica): A Light on Yorùbá History and Culture". In Holbrook, Jarita (ed). Astrophysics and space science proceedings - African Cultural Astronomy: Current Archaeoastronomy and Ethnoastronomy Research in Africa. Springer Science, New-York.

-. 2003. "The Scientific Mind and Cultural Articulation in an Oral Society: language as a mirror". Social Science Information, SAGE Publications (London, Thousand Oaks, CA and New Delhi) 42(3): 339-374.

Sègla, Dafon, Aimé, et Boko Adékin. 2006. “De la Cosmologie à la Rationalisation de la vie sociale: ces mots Idààisha qui parlent ou la mémoire d'un type de calendrier Yoruba ancien”. Cahier d'Etudes Africaines, 181 : 11-50.

Sibum, Otto. 1995a. "Reworking the Mechanical Value of Heat: Instruments of Precision and Gestures of Accuracy in Early Victorian England”. Studies in History and Philosophy of Science 26 (1): 73-106.

—. 1995b. "Working Experiments: A History of Gestural Knowledge”. The Cambridge Review Vol. 116 (n²325): 25-37.

—. 1998. "Des "Social Studies of Sciences" A L'histoire des Techniques: Les Gestes de la mesure, Joule, les pratiques de la brasserie et la science". In: Annales Histoire, Sciences Sociales, No. 4-5, Juillet-Octobre 1998, 745774.

Willet, Frank. 1967. Ife`in the history of West African sculpture. Thames and Hudson, London.

Zannou, Aimé, Gbaguidi Magloire, and Ahoussi-Dahouenon Edwige. 2016. “Chemical characterization of Tectonagrandis, Thaliageniculata, Lasiomorphasenegalensis and of Musa acuminata used as food packing's in Benin". Journal of Pharmacognosy and Phytochemistry 2016; 5(5): 79-82. 


\section{NOTES}

(1), (2), (3), (4) : Oral conversations with /égbinrin/ women sellers in village of Kèrè Igbo-Idààsha (Dassa-Zoumè), November 2013

(5), (6): Oral conversations with /égbinrin/ women sellers in village of Bourarou and Badé suburbs of Parakou, northern Benin, January 2014.

(7): Interview with a traditional healer and herbalist, village of Badé, suburb of Parakou, January 2014.

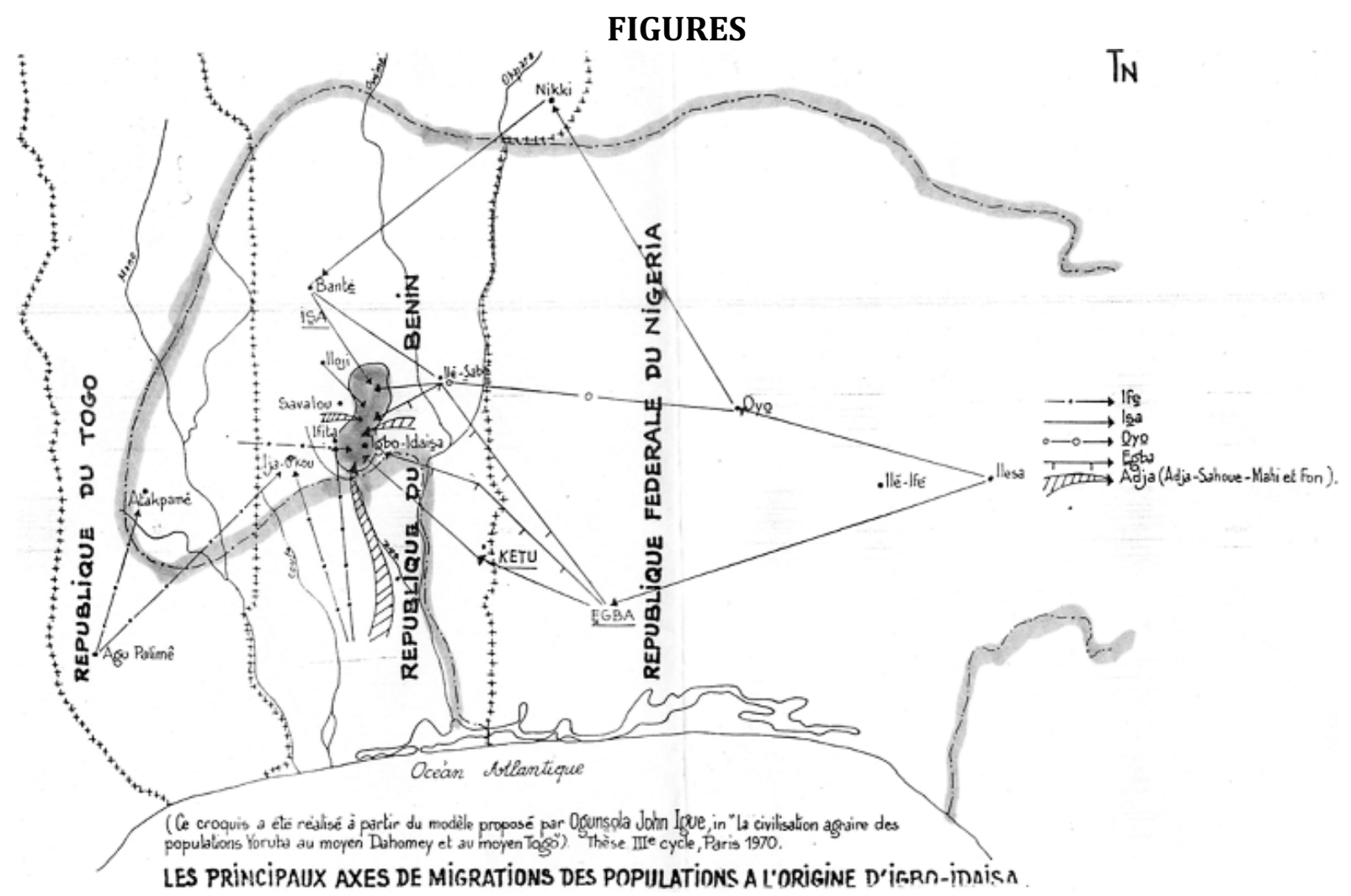

Fig. 1 Main Migration Axis at the Origin of Idààsha Linguistic Group within Yoruba Land

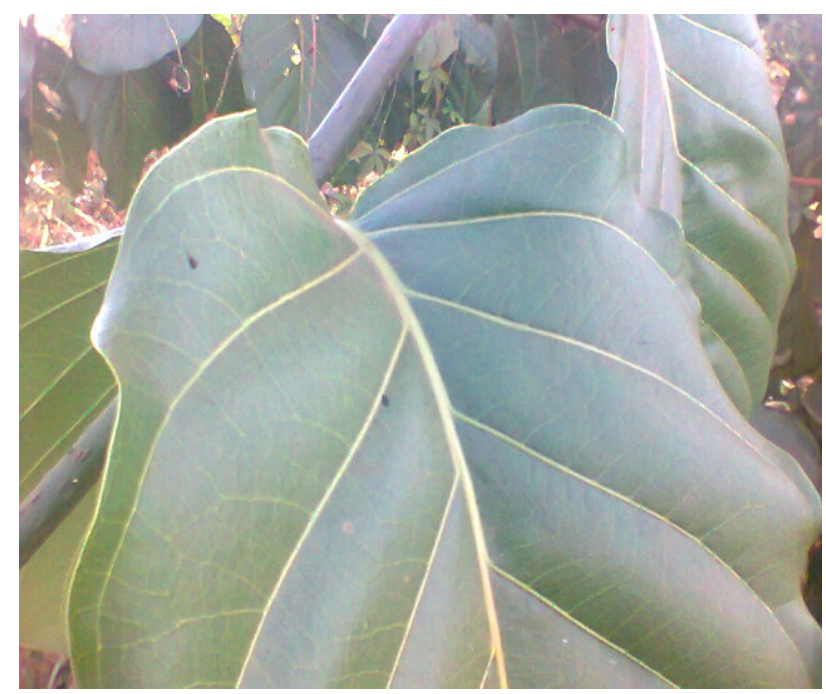

Fig. 2 Ewéègbessin (Ewé igbesin (Yoruba), garérou (Bariba)) leaf (Nauclea Latifolia or Sarcocéphalus Latifolius) 
Aimé, S. D., \& Simon, A. (2018). “The Role of a Yoruba Traditional Leaf in a Fermented Food Technology (Nauclea Latifolia, Sarcocéphalus Latifolius): Shedding Light on African Accuracy of Implicit Knowledge and Technologies". Advances in Social Sciences Research Journal, 5(2) $200-212$.
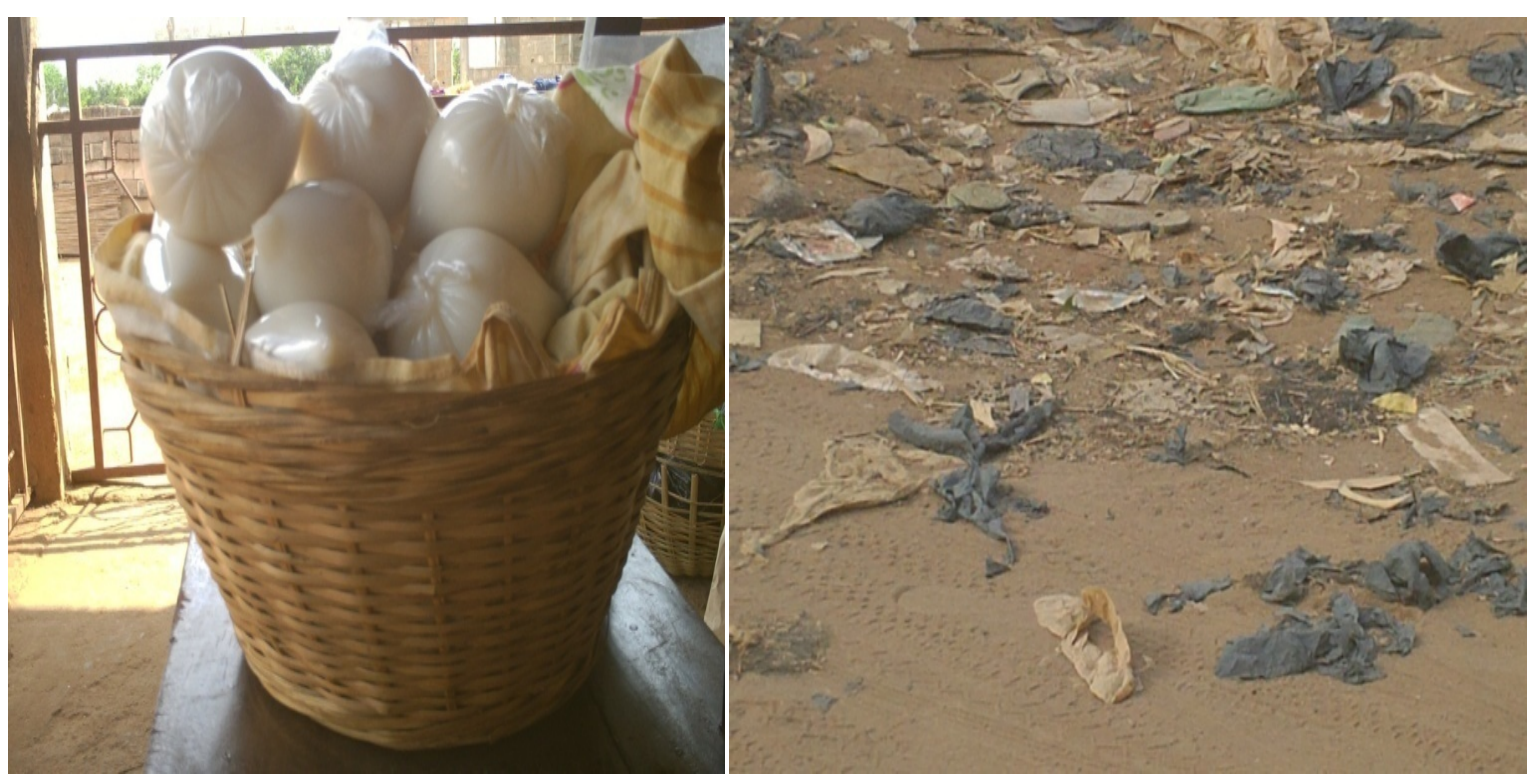

Fig. 3 Encapsulated Meals with Plastics (meal's name "Akassa") Leading to Pollution by NonBiodegradable Plastics

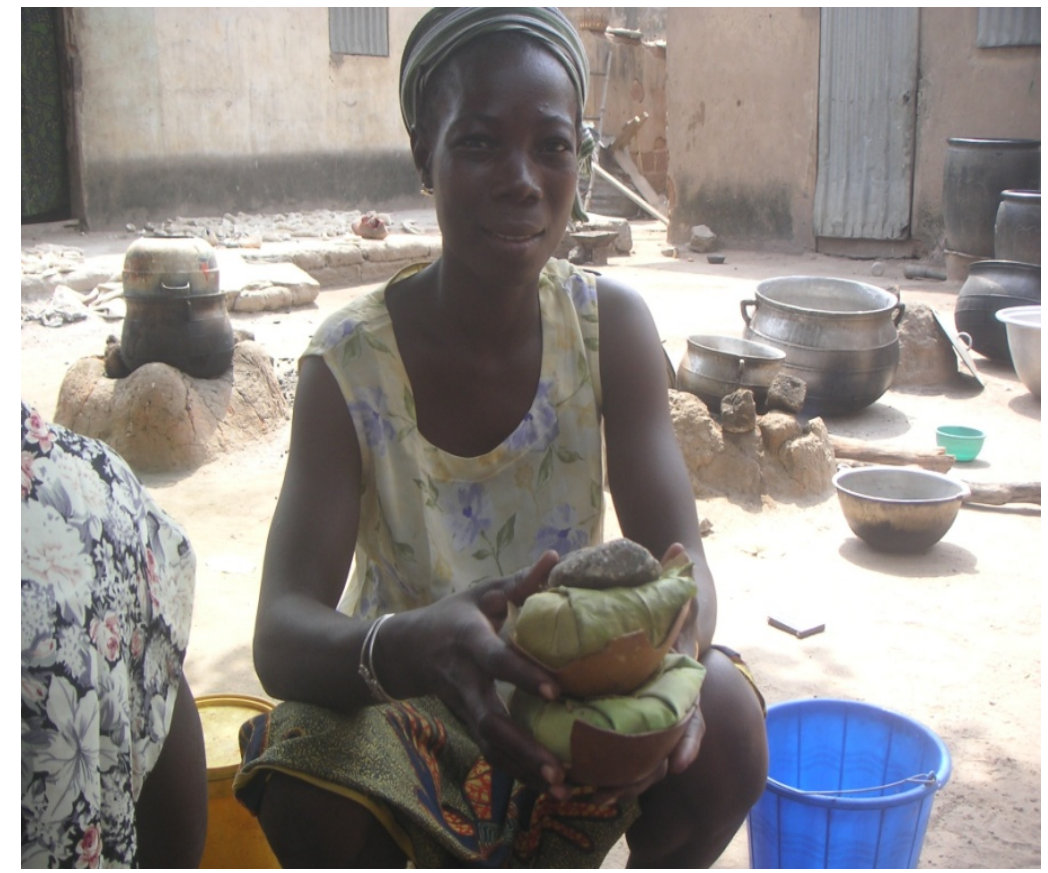

Fig 4 Ms. Adama Showing /Egbinrineko/ in /Egbessin; Garérou/ Leaf, and Putting it Inside a Traditional Gourde 


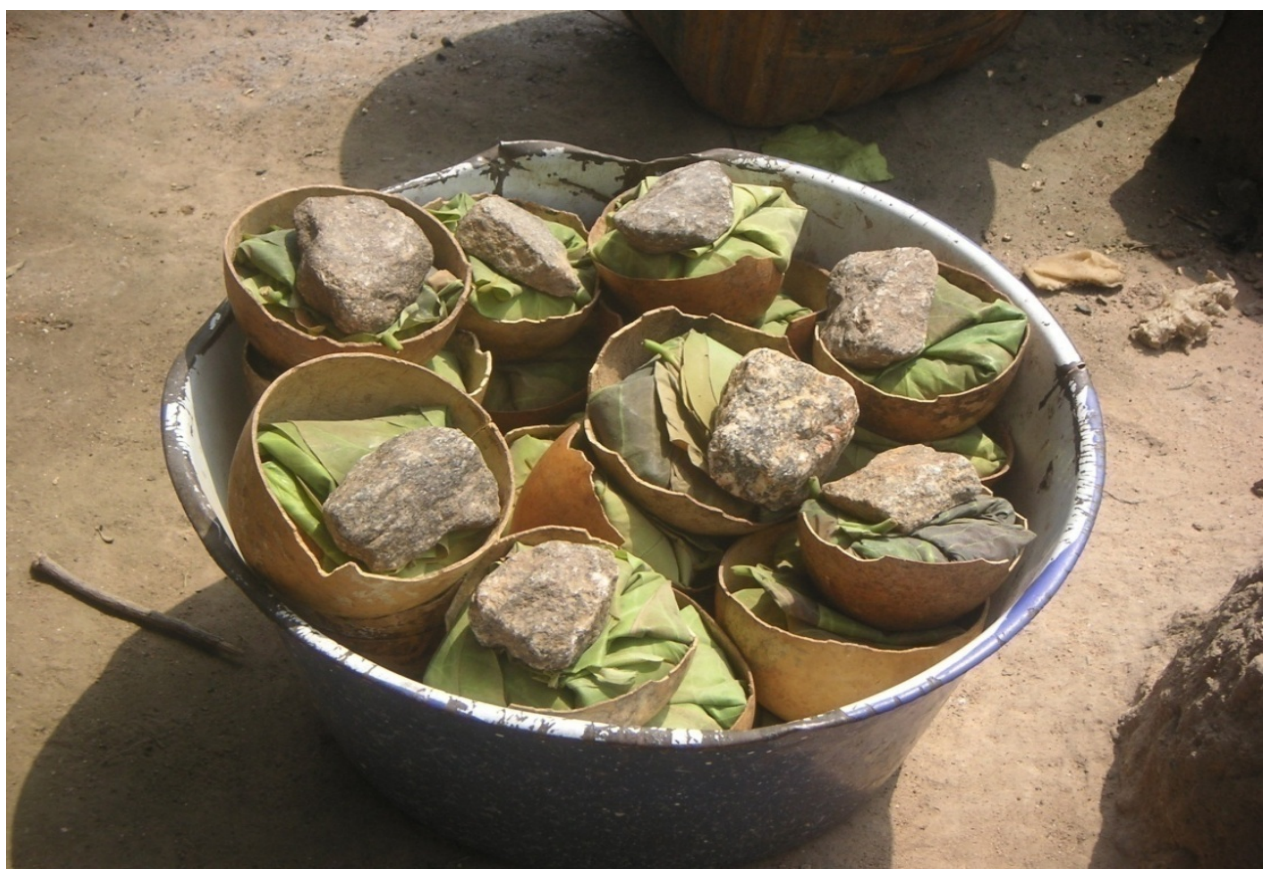

Fig 5 /Egbinrineko/ in /Egbessin; Garérou/ Leaf and Put Inside Traditional Gourds to Reinforce Protection

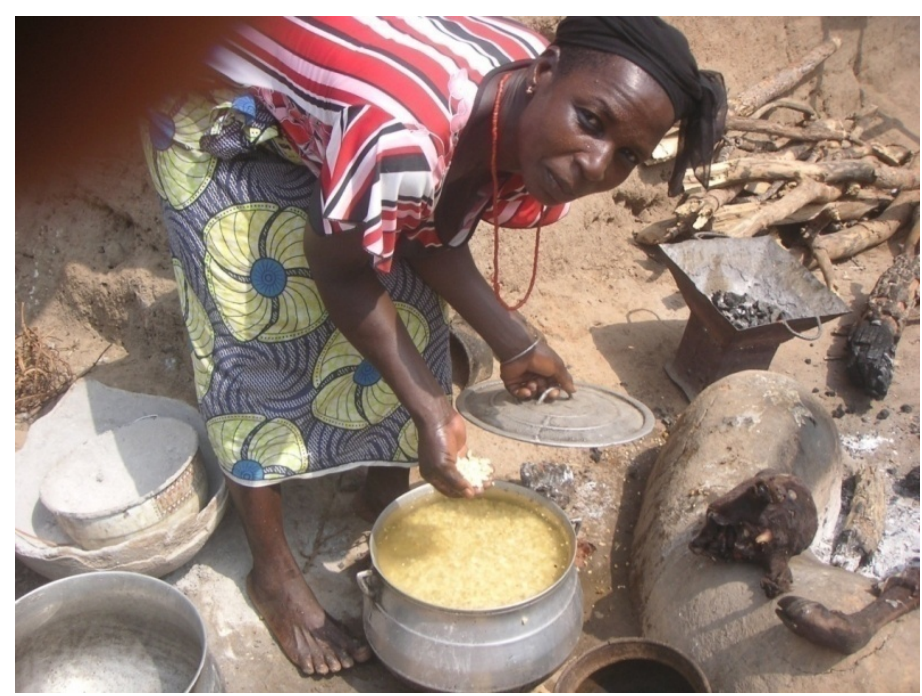

Fig 6 Ms. Na Bipibou Showing Fermented Maize 


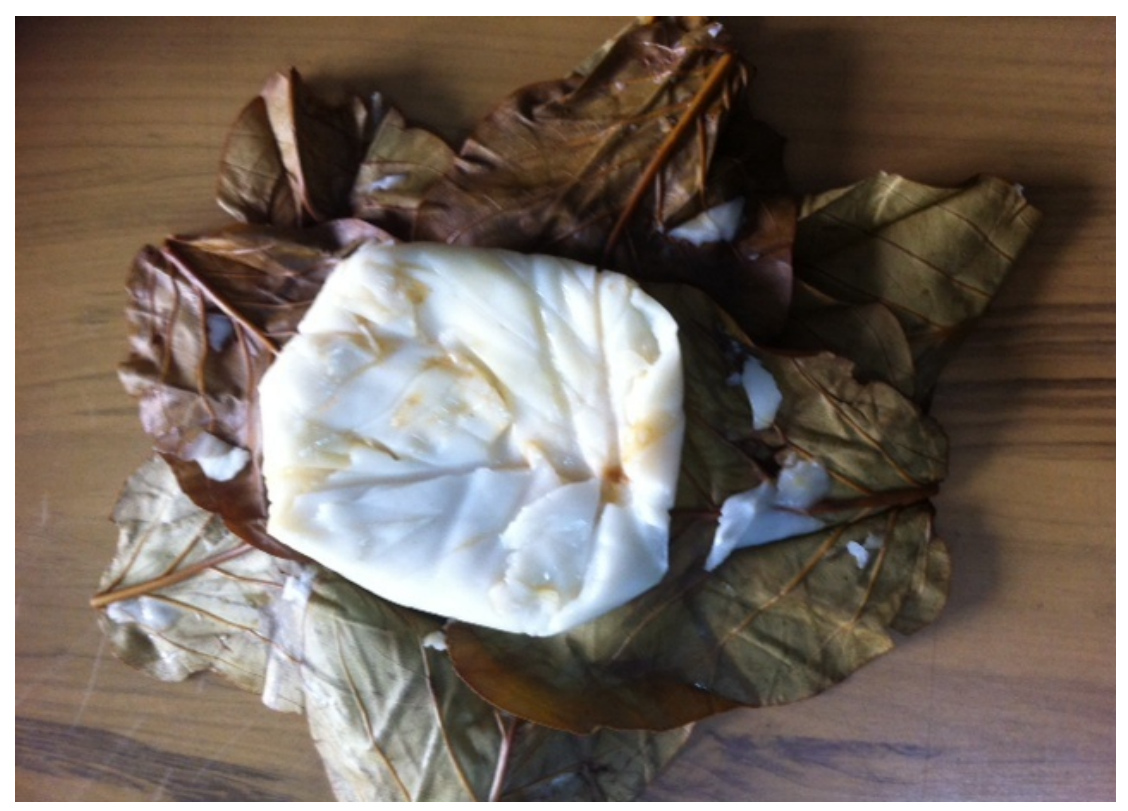

Fig 7 /Egbinrin eko/ in Opened /Egbessin/ leaf
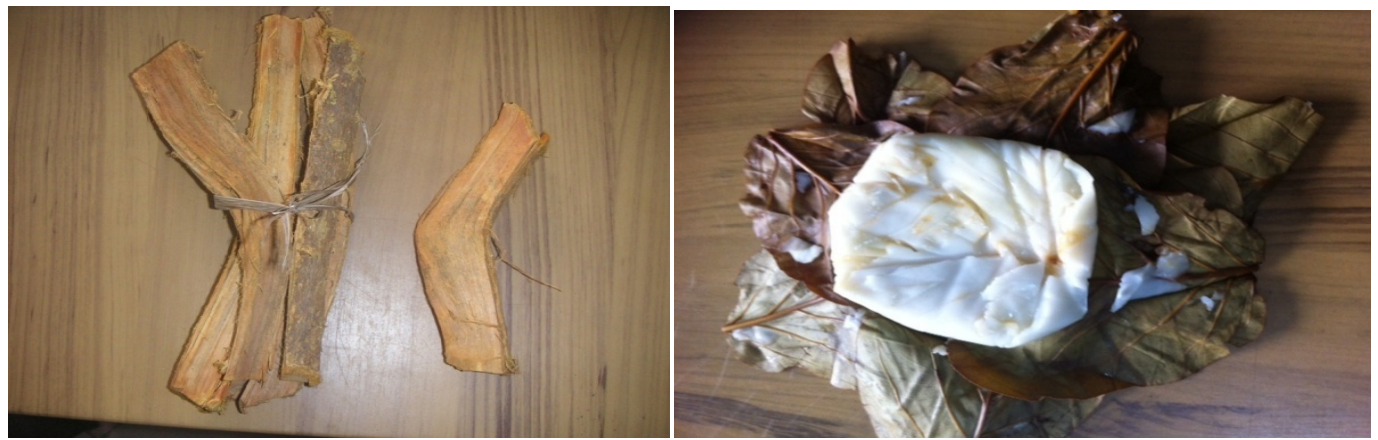

Fig 8 Sample of the /Egbessin/ Plant's Root: A Traditional Medicine as testified by Mr. Sambani Issifou 